Please cite this paper as follows:

Indraprahasta GS, Derudder B (2019) The geographically variegated connections of the Jakarta metropolitan area as produced by manufacturing firms. Growth and Change 50 (2), 705-724.

https://doi.org/10.1111/grow.12298 


\title{
The geographically variegated connections of the Jakarta metropolitan area as produced by manufacturing firms
}

\begin{abstract}
Connectivity in urban networks is often deemed to be an important feature of economically vibrant cities. Under conditions of contemporary globalization, the importance and geographies of these connections are increasingly variegated. Accordingly, various attempts have been made to analyse the external relations of cities and metropolitan regions, often through the lens of multi-locational firms. Our purpose in this paper is to address the to-date limited empirical knowledge about whether firms originating from different regions (i.e. firms with different headquarter [HQ] locations) create different patterns of inter-urban relations. Drawing on the interlocking network model and using the Jakarta metropolitan area (JMA) as a case study, this paper explores how manufacturing firms with HQs either inside (further differentiating between the JMA and other cities) or outside (further differentiating between East Asian and non-East Asian countries) Indonesia produce different patterns of external relations. Our findings indicate that each category of firms generates unique configurations of inter-urban relations for the JMA at the global and national scales. We argue that these variegated networks patterns not only reflect different locational strategies of firms, but also Indonesia's evolving policy orientations which have complex relations with evolving patterns of economic globalization.
\end{abstract}

Keywords: city networks, Jakarta metropolitan area, manufacturing, firm origins

\section{Introduction}

City networks are often deemed to be a generic feature of all urbanized societies and central to the economic dynamism of cities (Jacobs 1969; 1984; Taylor, Hoyler, and Verbruggen 2010). 
Indeed, city networks have been a core feature of the development of the capitalist worldeconomy whose genesis can be traced back to as the sixteenth century. As Braudel $(1984,96)$ put it: 'there could be no world economy until there was a dense enough urban network with trade of sufficient volume and regularity to breathe life into a central or core zone'.

However, since the 1970s the globalization of the world-economy has developed and expanded in more intricate ways than in earlier periods, leading to an increasing geographical extent and functional integration of economic activities between cities/regions (Dicken 2015). The welldocumented rounds of globalization since the 1970s have been enabled by a series of 'global shifts', including advancements in information and communication technologies (ICT) and transportation infrastructure system (Castells 1989; Graham and Marvin 2001), worldwide deregulation policies and privatization practices (Harvey 2005), and the rise of post-Fordist regimes entailing increasing specialization and flexibility in production systems (Amin 1994; Coe and Yeung 2015).

It is hardly surprising, therefore, that attempts to explore city networks have gained currency in the literature on cities in globalization (e.g. Smith and Timberlake 2002; Taylor and Derudder 2018). Some of this research sails under the flag of 'world city network' (WCN) research, which in its most basic guise is premised upon the view that (some) cities have developed into strategic nodes in a 'global space of flows', shaped by the network structures of transnational corporations (TNCs) (Friedmann 1986, 1995; Sassen 1991; Taylor 2004). Accordingly, various attempts have been made to allow identification of the globally most integrated nodes, as well as to uncover the overall structure and patterns of WCNs (e.g. Alderson and Beckfield 2004; Hoyler and Watson 2013; Martinus and Tonts 2015). In addition to such a 'top-down' perspective on WCN analysis, there has been growing interest in assessing the networks of cities that are not necessarily sitting at the apex of a global-scale urban hierarchy. Such a 'bottom-up' (Mans 2014) or 'contextually attuned' (Indraprahasta and Derudder 2017) 
approach to city networks may offer complementary insights into the WCN in two respects. First, it speaks to the increasing call to develop a more 'cosmopolitan' view in world city research by extending its geographical locus from the most affluent parts of the global economy to less affluent parts (see Robinson 2002). Second, such an approach may also provide a more nuanced understanding of the contextual specifics in which a particular city or metropolitan area is situated in the WCN (see Mans 2014; Olds and Yeung 2004).

To date, most studies using a bottom-up approach have focused on disclosing the urban network pattern of specific (sets of) cities (e.g. Hoyler, Freytag, and Mager 2008; Lüthi, Thierstein, and Bentlage 2013). However, this implies that we have little knowledge of whether firms with different geographical origins (i.e. firms headquartered in different countries or regions) may generate different urban networks. It has been argued elsewhere that the specific settings (e.g. institutional environments, business systems, etc.) in the home countries or regions of firms tend to influence firms' locational strategies (e.g. Fortanier 2007; Pauly and Reich 1997), thereby co-shaping city connectivity. This paper addresses this lacuna in the literature by zooming in on the experience of the Jakarta metropolitan area (JMA), arguably the key gateway between Indonesia and the global economy (Indraprahasta and Derudder 2017; Wall and van der Knaap 2011). The JMA comprises the Special Region of Jakarta and eight citylevel administrative areas, i.e. three kabupatens (Bekasi, Bogor, Tangerang Districts) and five kotas (Bekasi, Bogor, Depok, Tangerang, South Tangerang Municipalities). It is one of the most important industrial nodes in Asia, with the manufacturing sector having played a pivotal part in its globally-driven urbanization process (Hudalah and Aritenang 2017; Hudalah et al. 2013). Drawing on a set of 196 manufacturing firms from three sub-sectors that are economically central to the JMA in particular and to Indonesia more generally (i.e. electronics, automotive and transportation, and food and beverage industries), we explore and compare the urban networks in which the JMA is connected by differentiating between firms based on their headquarters 
(HQs) locations: (1) overseas (in East Asian countries or non-East Asian countries) and (2) Indonesia (in the JMA or in other cities).

The next section provides the theoretical background of this paper, discussing the relevance of a city network perspective in general and a bottom-up approach to WCN analysis in particular, as well as the particular context underpinning the JMA's economic vibrancy. The paper then continues with a brief description of the data and methods employed in this paper, after which we present our main results and provide a discussion in which we interpret the variegated nature of the JMA's connections. In the final section, we summarize our main findings and use these to outline some avenues for further research.

\section{Theoretical background}

\section{City networks connecting vibrant cities}

Scholarly discussions have gradually (re)cast the urban away from being a bounded, selfenclosed socio-spatial entity towards it being part of larger systems within which places are interwoven and interconnected (Brenner 2014a; Castells 2010; Taylor 2014). Drawing on Lefebvre's notion of 'planetary urbanization', Brenner (2014b: 17) argues that capitalist urbanization entails 'the mutually recursive links between capitalist forms of (urban) agglomeration and broader transformations of territory, landscape and environment'. In a similar vein, Taylor (2014; Taylor, Hoyler, and Verbruggen 2010) argues that urban economic development is characterized by two simultaneous but distinct processes, i.e. 'town-ness' and 'city-ness' processes. While 'town-ness' refers to the making of 'local' urban-hinterland relations, 'city-ness' refers the making of 'non-local' inter-urban relations. The latter idea is inspired by Jane Jacobs' (1969) thinking, in which she describes how urban-economic expansion occurs through of city networking. That said, the city-hinterland relation is a relatively stable relation, and is therefore less prone to economic changes. Accordingly, to expand urban 
economic activity, urban areas will require inter-urban relations that go beyond the agglomeration.

City-ness or city networking processes have indeed been a generic feature of vibrant cities (Jacobs 1969; Taylor 2012; Verbruggen 2011), for example in the early modern world-system marked by the rise and economic expansion of European cities (first the Italian cities and later the Dutch and British cities) between the fifteenth and nineteenth centuries; the United States (US), German, and Japanese cities in the late nineteenth and twentieth centuries; and East Asian cities in the late twentieth and twenty-first centuries (Derudder and Taylor 2018; Taylor, Hoyler, and Verbruggen 2010). Advances in technological development, especially in terms of transport and communication, as well as a series of fundamental changes in the world-capitalist system have bolstered the interaction and mutual interdependence of cities across the globe (Castells 2010a; Pflieger and Rozenblat 2010). Indeed, the current round of globalization is characterized by 'the formation of a new spatial architecture in our planet, made up of global networks connecting major metropolitan regions and their areas of influence' (Castells 2010b, 2737).

In an increasingly interconnected world, then, the importance of cities is increasingly defined by their external relations and their positionality in global networks of cities (Castells 2010a; Sheppard 2002). Accordingly, since the 2000s we have witnessed a proliferation of empirical studies that explicitly seek to unpack the global networking potential of cities. In general, two major approaches have been used to map the contours of a global network of cities: the 'infrastructure' and 'corporate organization' approach (Derudder 2006). Studies conducted through the infrastructure approach start from the observation that important cities are key nodes in the infrastructures underpinning boundary-crossing networks, most notably telecommunication (e.g. Rutherford 2005; Townsend 2001) and transportation (e.g. Ducruet, Ietri, and Rozenblat 2011; Smith and Timberlake 2002). The most important urban centres also 
harbour the most important airports and, to a certain extent, ports, while vast optical fibre networks have equally been installed within and between major metropolises. Meanwhile, the corporate approach starts from the observation that inter-urban relations are primarily created by firms pursuing transnational locational strategies (e.g. Alderson and Beckfield 2004; Taylor and Derudder 2016). This line of thinking has been mainly influenced by Friedmann (1986; Friedmann and Wolf 1982) and Sassen (1991), who posited that TNCs and their advanced service providers are the key shapers of the geographies of the global economy. Recently, this literature has diversified to incorporate other dimensions of global prominence, ranging from institutions of higher education (Chow and Low 2015) to media firms (Hoyler and Watson 2013). Regardless, from this perspective cities are deemed to be the 'basing points' or 'strategic nodes' of the global economy that are connected through cross-border flows generated by multi-locational agents such as TNCs. In this paper, we marshal this approach to explore the structure of city networks. In the next sub-section, we elaborate on a specific part of this strand of literature that is of particular relevance for our paper.

\section{World city network analysis: A 'bottom-up' perspective}

The WCN research agenda can be envisaged as an attempt to abstract and understand the global economy through the lens of cities (Harrison and Hoyler 2018). It is premised upon the view that global networks of cities provide the organizational scaffolding of the global economy, and the most connected cities function as the 'command-and-control' posts for global economic operations. Much of this research agenda originally focused on the identification of the most connected nodes in the WCN. The WCN research agenda thus extends the writings of John Friedmann (1986; 1995) and Saskia Sassen (1991) who have identified a small number of major cities that could deemed to be 'world' or 'global' cities (e.g. London, New York, Tokyo). By including many more cities across the globe into the analysis, the WCN research has thus provided a somewhat more inclusive account of cities in globalization. 
The WCN research agenda has gradually established itself as a diverse intellectual endeavour in conceptual and empirical but also in methodological terms, aiming to understand how cities are inserted in various global networks. For instance, there are at least two different empirical network models that have been commonly used to project corporate networks into urban networks (Liu and Derudder 2013). First, some researchers specify inter-city relations by looking at ownership linkages running from HQs to the subsidiaries of a firm (e.g. Alderson and Beckfield 2004; Krätke 2014; Martinus and Tonts 2015; Wall and van der Knaap 2011). In this approach, the urban network specification is straightforward in that HQs-subsidiaries linkages indicate flows of directive and information between cities. Second, some researchers, most of them associated with the Globalization and World Cities (GaWC) research network, have drawn on the so-called the interlocking network model (INM) for specifying urban networks (e.g. Hoyler and Watson 2013; Taylor and Derudder 2016). In this approach, the urban network is 'denser' in that it is assumed that all locations of a firm are connected through information flows. A range of inter-city networking processes have thus been studied, jointly grasping the 'multiple globalization' of cities in different economic sectors, including (but not limited to) producer services (Taylor et al. 2014), manufacturing industries (Krätke 2014), and energy corporations (Martinus and Tonts 2015). These analyses collectively recognize the different roles of cities in the global economy. That said, irrespective of the data source and the methodological framework used to specify how multi-locational firms 'network' cities, the above-referenced literature starts from a definition of 'important' or 'global' firms, so that city connectivity is 'measured' irrespective of cities' broader economic-geographical context.

In recent years, a parallel empirical framework - which some (e.g. Lüthi, Thierstein, and Hoyler 2018; Mans 2014; Schmitt and Smas 2012) have called a 'bottom-up' approach - has been devised to pursue a similar objective: investigating the external networks of cities. However, instead of analysing the WCN as a singular object of study, studies sailing under this flag investigate the connectivity of a particular city or sets of cities by focusing on the key drivers of 
that connectivity. A bottom-up approach, therefore, starts with firms or other agents that are central to the specific geographical (urban, city-regional, or national) settings. Accordingly, these studies have used firms of varying size ranging from small firms with limited multilocational operations to large transnational firms with operations across a large number of countries.

Depending on the research question, there may be some advantages to using a bottom-up approach to the analysis of city networks. First, as it attunes the framework to relevant geographical contexts, a bottom-up lens provides an alternative and complementary reading of how a city or sets of cities are articulated into the WCN. In particular, a more nuanced understanding of the contextual specifics in which a particular city or set of cities is situated in the WCN is approached by using particular firms (or sectors) that better capture the urban economic dynamism of that city or set of cities (e.g. Indraprahasta and Derudder 2017; Lüthi, Thierstein, and Goebel 2010; Schmitt and Smas 2012). Second, as the bottom-up approach produces a more cosmopolitan view of world cities, it helps improving our understanding of the extra-local relations and positionality of a city that is located in the less affluent parts of the global economy. Some examples are the studies by Mans (2014) on Khartoum (Sudan) and by Indraprahasta and Derudder (2017) on the Jakarta metropolitan area (Indonesia). Third, by using firms of varying size, including 'local' and 'national' firms, this approach enables to identify the role of small- and medium-sized cities/towns which are usually less visible in topdown assessments (e.g. Lüthi, Thierstein, and Bentlage 2013; Zhang and Kloosterman 2016).

Despite the merits of this bottom-up approach, only limited attempts have been made to explore whether firms with different geographical origins (i.e. firms headquartered in different countries or regions) generate different urban networks. The influence of firms' origin on their business organisations and strategies has been studied quite extensively, especially in the field of international business and economics (e.g. Fortanier 2007; Pauly and Reich 1997). A common 
finding is that a wide range of firms organisational and strategic characteristics is built through engaging with the particular institutional environments and business systems in their home regions. Distinctive national institutions and cultural characteristics of firms' home regions continue to shape and channel crucial corporate decisions, including their location choices (Goerzen, Asmussen, and Nielsen 2013). As such, even in an increasingly globalized world, TNCs' core business strategies are not simply converging towards common patterns. This divergence by origin, therefore, further influences the interaction between firms and the host economies in varying ways, including investment and marketing strategies in general and location decisions in particular. Taking the insights of these studies into consideration, it would therefore be interesting to understand the implications of firms' HQs locations to the urban networks they generate. In this paper, we attempt to capture the different patterns of urban networks in which the JMA is connected by differentiating between firms by virtue of their HQ locations: (1) overseas (in East Asian countries and non-East Asian countries) and (2) Indonesia (in the JMA and in other cities). The next sub-section then takes a closer look at the particular context driving the JMA's economic vibrancy under conditions of contemporary globalization.

\section{Manufacturing and the JMA's economic vibrancy}

As noted earlier, a bottom-up perspective foregrounds the economic-geographical context in which a city is located. It is therefore important to understand the context underpinning the economic vibrancy of the JMA under conditions of contemporary globalization. A range of studies has linked the rise and global integration of the JMA to the global industrial relocation processes that started unfolding in the late 1980s (e.g. Firman 1998; Lo and Yeung 1996; Soegijoko 1996). Being privileged as the country's economic nerve centre for decades, a large part of this global industrial capital has manifested itself in and through the JMA (Indraprahasta, Derudder, and Koelemaij 2018). For instance, about half of all cumulative foreign direct investment (FDI) inflows into Indonesia between 1990 and 1997 was absorbed by the JMA alone. Overall, it can be argued that the early 1990s were a golden era for the Indonesian 
economy, largely sustained by the industrial boom. Not surprisingly, Indonesia (together with Japan, South Korea, Taiwan, Hong Kong, Singapore, Malaysia, and Thailand) was classified in 1993 as a 'high-performing Asian economy' by the World Bank (World Bank 1993, xvi).

This industrial era, however, seemed to come to an abrupt end with the onset of the 1997-1998 Asian financial crisis that hit the country hard. Some argued that the Indonesian economy even experienced the worst impact in East Asia (e.g. Hill 1999). This financial crisis severely affected the country in economic and political terms, including its urban development (Firman 1999a; 1999b). For instance, unemployment strongly increased as many manufacturing and services firms had gone into bankruptcy and the domestic and foreign investment to the country (including to the JMA) declined suddenly and substantially. In political terms, this crisis had also led to a radical shift in the Indonesian political system, from a centralized regime towards a more democratic and decentralized government system, known as otonomi daerah (regional autonomy).

After about a decade of gradual recovery, the country has witnessed notable economic growth again. At the same time, the global economic landscape has changed. The most prominent change has arguably been the rise of China - which was not really or at least not as much affected by the 1997-1998 financial crisis - as a new global economic power, including in the manufacturing sector. This changing global environment has in many ways affected the industrial dynamics in many emerging Southeast Asian countries, including Indonesia (e.g. Hamanaka 2011). Despite this changing global and national economic context, the JMA has retained its status as the country's major industrial hub (Hudalah and Aritenang 2017). This can, to a large extent, be ascribed to the fact that the Indonesian national government tends to support manufacturing activities, mainly those of non-agricultural- and non-resource-based industries, within and surrounding major metropolitan areas in Java, including the JMA (Indraprahasta and Deruddder 2017). It can be observed that, in terms of economic output, 
about a quarter of Indonesia's gross domestic product (GDP) in manufacturing sector is produced in the JMA alone (BPS 2016).

Taken together, the manufacturing sector has been the key sector paving the way for the deeper insertion of the JMA into the global economy, and has established the metropolis' positioning as the country's industrial hub. Accordingly, in this paper, we use this sector as an indicative vector of the JMA's articulation into the WCN.

\section{Data and methods}

\section{The interlocking network model}

In this paper, we marshal the interlocking network model (INM; Taylor 2001), which can be used to capture generic processes of city network formation (Derudder and Taylor 2018). The basic idea underlying the INM is that cities are interconnected by exchanges in the office networks of firms, reflecting the investment conditions and potential values of different places from the perspective of firms' (long-term) location strategies. A city chosen by a firm to be a part of its office network is interlocked with other cities through a wide variety of flows (capital, information, ideas, people, etc.) within this network. The INM therefore uses a proxy - i.e. offices of multi-locations firms - to estimate potential flows between cities. In this respect, one the main limitation of the INM lies in its limited attention for extra-firm networks. At the same time, intra-firm trade in TNCs accounts for an increasing portion of international trade in today's global economy (OECD 2008). In general, as put forward by Lüthi, Thierstein, and Hoyler (2018: 288), 'the INM provides one specific way of addressing the question as to how inter-city relations can be empirically measured despite the chronic lack of data on inter-city flows'.

The operationalization of the INM requires an $n \times m$ matrix $V$, summarizing the locational strategies of $m$ firms across $n$ cities. The values in the matrix cells estimate the importance of the individual office/enterprise unit of a firm $j$ in city $i$ through a standardized 'service value' $v_{i j}$. 
The crux of this model is the calculation of the inter-city relation or city-dyad connectivity $\mathrm{CDC}_{a}$ $b$ between cities $a$ and $b$ for each pair of cities and firms based on $V$ :

$C D C_{a-b}=\sum_{j} v_{a j} \cdot v_{b j} \quad($ where $a \neq b)$

The above equation is basically a bipartite projection function, where location information of agents or firms (two-mode: cities/agents) is transformed into information on inter-locational networks (one-mode: cities/cities) (Liu and Derudder 2012). Based on this specification, a city's total network connectivity, $\mathrm{TNC}_{a}$ can be calculated by aggregating all possible links.

$T N C_{a}=\sum_{b} C D C_{a-b}=\sum_{b j} v_{a j} \cdot v_{b j} \quad($ where $a \neq b)$

\section{Data collection}

\section{$\underline{\text { Selecting firms }}$}

We collected data on the most important manufacturing firms from three key industrial subsectors for the JMA in particular and Indonesia more generally: electronics, automotive and transportation, and food and beverage (for further explanation, see Indraprahasta and Derudder 2017). The firm data were collected from three main sources: Forbes 2000 (as of 2015), the Indonesia Stock Exchange (IDX) (as of 15 July 2015), and the National Industrial Database (as of 2014). The first source has been widely used in top-down appraisals of the WCN, including those that are based on media firms (Hoyler and Watson 2013) and manufacturing industries (Krätke 2014). Meanwhile, while the IDX consists of all the publicly listed companies in Indonesia (mostly large national firms, including from the manufacturing sector), the National Industrial Database (published by the Indonesia Statistical Office or BPS) includes all foreign and domestic manufacturing firms in Indonesia. A firm is selected if it has at least two offices/enterprise units of which at least one is located within the JMA. All firms listed in Forbes 2000 and IDX that have multi-locational operations (at least with one 
office/enterprise unit is located in the JMA) are thus included. Specific to the National Industrial Database is that, in addition to the previous criterion, a firm is selected if it belongs to the largest manufacturing firms in Indonesia, measured by means of employment size. The National Industrial Database is used to identify 'smaller' and 'less global' firms vis-à-vis those listed in the two previous sources. Although the number of firms in the National Industrial Database is quite large, most of them are single-office firms, and therefore they cannot be used for network analysis. In particular, firms having less than 100 workers tend to be single-office firms, and were therefore excluded from our database. The final database thus contains the majority of important multi-location firms in the three industrial sectors in the JMA, consisting of a basic set of 196 firms (53 in electronics, 73 in automotive and transportation, and 70 in food and beverage). Of the 196 firms under study, 134 are headquartered across 47 international cities, whereas the rest are headquartered across 14 Indonesian cities (Table 1).

Table 1. Distribution of firms' HQs

\section{Assigning service values and selecting cities}

The next step was allocating a service value $\left(v_{i j}\right)$ to each city/firm pair, indicating the importance of a particular city within a firm's overall multi-locational networks. Because manufacturing firms operate within a diverse set of interconnected activities, ranging from managerial to production functions, we include all of the firms' enterprise units, except for small local sales offices. The omission of small local sales offices was in particular executed for firms in the automotive industry because these offices are ubiquitous and they often only have weak connections with the firm holding. Information for every firm's enterprise unit was standardized into service values ranging from 0 to 5 as follows: 5 for global HQs, 4 for regional HQs or global HQs of smaller firms (having no more than 20 enterprise units), 3 for national HQs, 2 for ordinary offices/units, 1 for offices/units with reduced functions, and 0 if there is no 
presence. This weighting applies a certain degree of standardization to complex firm activities and varying sizes of firm.

All cities in which enterprise units (excluding small local sales offices) of our 196 firms are located are included in our analysis. Adjacent cities were grouped into metropolitan areas. The classification of these metropolitan areas is based on metropolitan area classifications from each country, such as the Urban Employment Area (UEA) in Japan and the Metropolitan Statistical Areas (MSA) in the US. Some judgment calls were made for extended metropolitan areas: for example, we merged the cities of Toyota, Miyoshi, and Anjo into the Nagoya metropolitan area. The end product of this data collection is a city-matrix detailing the presence of 196 firms spread across 58 Indonesian cities/metropolises (including the JMA) and 1850 international cities/metropolises. The exercise of establishing our city-firm database took about five months, running from September 2016 to January 2017.

\section{Results and discussion}

In this section, we explore the different patterns of the JMA's external relations generated by firms with different HQs locations, notably overseas (East Asian and non-East Asian) firms and domestic (JMA and non-JMA) firms. We start by discussing the connectivity patterns at the global scale, and then zoom in on the national scale.

\section{Global connections of the JMA}

The global connections of the JMA are roughly equally produced by East Asian and non-East Asian firms: firms from East Asian countries produce about 47\% of the JMA's global total network connectivity, while firms from other countries (European countries and the US) produce about $52 \%$ of this connectivity. Meanwhile, domestic firms only create less than $1 \%$ of the JMA's global connections. 
Table 2. Top twenty-five global connections of the JMA for firms with different HQs locations

These overseas firms have, however, different patterns of global connections. Firms with HQs located in East Asia mostly connect the JMA to other major urban centres within the same region (Figure 1). The ten most-connected cities with the JMA are all East Asian cities with Tokyo, Singapore, and Bangkok atop the ranking. In total, more than half of cities listed within the twenty-five most-connected cities with the JMA are East Asian cities (Table 2). Perhaps unsurprisingly, this geographical pattern corresponds with a recurring finding in the literature pointing to East Asia's economic interdependence (Kimura 2006). In fact, it has been argued that the economic interdependency within East Asia has been increasing steadily over the last decades with TNCs originating from this region having played a significant part in the regional integration (e.g. Athukorala and Yamashita 2006; Fujita 2007).

Meanwhile, compared to their East Asian counterparts, firms with HQs located in Europe and the US produce relatively more balanced inter-urban networks (Figure 2). It can, for instance, be observed that the distribution of CDC values of the twenty-five most-connected cities generated by non-East Asian firms is flatter than the East Asian ones. Another interesting observation is that firms headquartered in these non-East Asian countries link the JMA to relatively more cities outside East Asia, most notably urban centres in Europe. For instance, there are nine European cities vis-à-vis ten East Asian cities listed in the twenty-five most-connected cities (Table 2). Besides Paris and London - the two traditional gateways of Europe (Alderson, Beckfield, and Sprague-Jones 2010; Taylor and Derudder 2016), there are several major cities located in Eastern and Southeastern Europe, i.e. Moscow, Warsaw, Athens, Istanbul, and Prague. As has been reported elsewhere, some countries in these parts of Europe have experienced notable economic growth in recent years, making themselves increasingly attractive for new businesses (e.g. Holmes 2018). With the expansion of firms' (transnational) activities, major cities in these 
countries have in turn become interconnected, functioning as the strategic loci for the globalization and networking of nations and corporations.

Figure 1. Top forty-five global connections of the JMA for firms with HQs location in East Asian cities (source: map by Free Vector Maps, http://freevectormaps.com)

Note: The CDC is shown as a proportion of the most connected city-dyad with the JMA (Tokyo)

Figure 2. Top forty-five global connections of the JMA for firms with HQs location in non-East Asian cities (source: map by Free Vector Maps, http://freevectormaps.com) Note: The CDC is shown as a proportion of the most connected city-dyad with the JMA (Singapore)

Taken together, the different patterns of the JMA's global connections created by overseas firms with different HQs locations broadly reflect the different location choices of these firms. A general explanation would be that even in a world with increasing globalization, regional strategies still dominate TNC location strategies (Frigant and Zumpe 2017; Rugman and Verbeke 2004; 2005), with East Asian firms tending to exhibit stronger regional integration visà-vis their counterparts in Europe and North America (Athukorala and Yamashita 2006).

Among the domestic firms, it is above all firms headquartered in the JMA that produce the JMA's global connections: only one firm with HQs located outside the JMA has an overseas operation (in Kuala Lumpur). While these JMA-based firms only contribute a small portion to the JMA's global connections, they produce a relatively unique network pattern vis-à-vis that of overseas firms. In addition to the East Asian connections, these firms link the JMA to a variety of cities in the Middle East and African countries (Figure 3). All of these overseas networks are produced by firms in the food and beverage industry. These two regions continue to be one of the most favourable 'landing places' for Indonesia’s overseas investments (Sheany 2018; Yuswohady 2014). The future prospects of these regions (in particular Africa) from an Indonesian perspective can for instance be seen by the recent 'Indonesia-Africa Forum 2018' event, in 
which one of its commitments deals with the expansion of Indonesian firms and products to African countries. More generally perhaps, this geographical pattern can be ascribed to the observation that an increasing number of countries in these regions have experienced sustained economic growth, making them attractive places to invest (in a wide variety of sectors) as well as to expand markets (Bassens, Derudder, and Witlox 2010; Leke et al. 2010). Another possible reason is religious proximity, in that the industrial (mainly food and beverage) products entering the Middle East and North Africa region (in which the vast majority of the people are practicing Islam) should comply with 'halal' certification (Rakhmat 2016).

Figure 3. Top twenty-five global connections of the JMA for firms with HQs location in the JMA (source: map by Free Vector Maps, http://freevectormaps.com) Note: The CDC is shown as a proportion of the most connected city-dyad with the JMA (Kuala Lumpur, Singapore, and Lagos)

Overall, Singapore appears at the apex of the JMA's global connections in all categories, with the exception of non-JMA-based firms. This city-state functions as a switching point that channels both global outward and inward flows. Generally speaking, endowed with cutting-edge technologies (notably in communication and transportation), high-end financial services, and supportive government policies, Singapore has firmly established its global position as the regional gateway that links major urban centres in Southeast Asia to the global economy (Indraprahasta and Derudder 2017; Yeung and Olds 1998). Another influential factor making Singapore an ideal location for firms from both the East and the West to locate their regional offices therein would be its diverse cultural profile: a cosmopolitan society with a mixture of Malay, Chinese, Indian, European, and American influences. As has been argued elsewhere, cultural proximity and diversity do have a profound impact on the TNCs' business strategies (e.g. Hennart and Larimo 1998; Luo 1997). 


\section{National connections of the JMA}

The JMA's national connections are not only generated by the organizational networks of domestic firms but also the foreign ones. Despite the fact that the domestic firms are the major network shapers within the national territory (i.e. about 38\% of the JMA's total network connectivity at the national level is produced by the JMA-based firms and about $27 \%$ of this connectivity is contributed by non-JMA-based firms), overseas firms also contribute quite significantly: about $22 \%$ and $14 \%$ of the JMA's national connections are contributed by EastAsian-based and non-East-Asian-based firms, respectively. This figure implies that the globalization process of the JMA generated by foreign actors has not simply created a space of exclusion but has also spilled over into other Indonesian cities.

Table 3. Top ten national connections of the JMA for firms with different HQs locations

These overseas corporations have, however, created different patterns in terms of JMA's national connections (Table 3). On the one hand, East Asian firms tend to connect the JMA to cities that largely function as production sites. Outside Surabaya, it can be observed that four cities known to be the country's industrial centres (i.e. Karawang, Batam, Pasuruan, and Purwakarta) sit atop the JMA's national connections. On the other hand, non-East Asian firms largely connect the JMA to Surabaya, Indonesia's second largest urban agglomeration. As noted earlier, these different patterns clearly reflect the organizational and locational strategies deployed by East Asian and non-East Asian corporations that tend to form production networks within their respective regions (Dicken 2005; Oh and Rugman 2012). In this respect, the strong connectivities of 'production cities' created by the former firms are certainly in line with Indonesia's entrenched integration into the complex and extensive web of East Asian production networks centred on Japan, and later the newly industrializing economies (Ando and Kimura 2005; Athukorala and Yamashita 2006). On the contrary, while European and American firms do oversee production activities in Indonesia, their establishment is less 
ubiquitous than their East Asian counterparts. Interestingly, these non-East Asian firms are also involved in one particular activity that the East Asian corporations tend not to in Indonesia: research and development ${ }^{1}$. For instance, Mars Inc. has established one of its research centres in Luwu Timur, a peripheral region located in the island of Sulawesi, while Apple Inc. has planned to establish an innovation hub in the JMA.

Meanwhile, domestic firms headquartered in the JMA generate relatively more decentralized inter-urban networks compared to those headquartered in other Indonesian cities (Table 3). The former firms link the JMA to a relatively wide variety of cities. On the other hand, the JMA's national connections created by the latter firms are strongly geared towards the most prominent 'regional centres': the traditional urban centres of Java (i.e. Surabaya, Semarang, and Bandung) and the major hubs of Sumatera (i.e. Medan) and Bali (i.e. Denpasar). This figure obviously suggests different locational strategies used by firms from different regions. A possible reason could be that firms headquartered in cities outside the JMA have more limited resources (financial, personnel, etc.) so that these firms tend to focus on expanding their businesses in regions with the highest market potential (Investor Daily 2011; Salna and Amin 2018). It is worth noting that the metropolitan areas of Surabaya, Bandung, Semarang, and Medan are Indonesia's largest urban agglomerations after the JMA (BPS 2011), while Denpasar is the capital city of Bali - one of the key tourist destinations in the world 2 .

Taken together, the mapping of the JMA's national connections reveals the centrality of Surabaya in the networks produced by all four categories of firms. Surabaya is the mostconnected city alongside the JMA in all categories, except for the networks generated by East Asian firms: Surabaya is obviously the second choice for many foreign and domestic firms to locate their enterprise units. Firms can benefit from the urban and agglomeration economies

\footnotetext{
${ }^{1}$ As reported by some, a low wage level is still an important motivation for East Asian (notably Japanese) firms to invest in developing East Asia (e.g. JBIC 2015; Kimura 2006)

${ }^{2}$ For instance, according to 2018 Travelers' Choice Award, Bali is ranked as the fourth best destinations in the world (https://www.tripadvisor.com/TravelersChoice-Destinations-cTop-g1)
} 
that this metropolis generates: existing industrial concentrations, labour market pooling, (internal and external) market potential, a cosmopolitan environment, and a well-developed infrastructure system. Overall, the JMA and Surabaya are the two major economic powerhouses of the country, with the latter complementing the former's role in the national territory as a gateway to the eastern parts of Indonesia (Indraprahasta and Derudder 2017). It is worth noting that the current strategic position of Surabaya is a product of its long-term evolutionary process: it was once one of the most important entrepots in the Indonesian archipelago before the arrival of the European colonialists (Reid 1980) and a key industrial centre during the Dutch colonial period (Dick 2002). As Dick (2002, xvii) aptly puts it: 'the modern history of Indonesia especially of Java - can be read as a tale of two cities, Jakarta (colonial Batavia) and Surabaya'.

\section{Conclusions}

Our main objective in this paper has been to enrich empirical studies using a bottom-up perspective to WCN analysis by zooming in on the experience of the JMA. Drawing on the INM, we have found that firms with different HQs locations generate distinct network patterns for the JMA at different geographical scales.

On the one hand, the JMA's global connections are equally shaped by both East Asian and nonEast Asian firms. As previously discussed, the regional tendencies embedded in TNCs' global strategies have influenced the way these firms generate (different) global networks of cities in which the JMA is articulated. On the other hand, there is also a clear indication that domestic (most notably JMA) firms have 'gone global', albeit with a limited global reach, thereby generating 'alternative' global urban networks. In addition to the usual East Asian urban networks, the JMA's global connections created by JMA firms are geared towards cities in the Middle East and African countries. Broadly speaking, this pattern reflects 'the changing contours of the global economic map' characterized by the deepening integration of the emerging economies in the global economy in general (Dicken 2015) and increasing South-South 
investment (including between African countries and other developing countries) in particular (Gelb 2005). These changing contours tend to resonate with broader shifts in connectivity in the WCN: the rising global connectivity of Middle East and Africa regions in general and of Dubai and Johannesburg in particular (Derudder and Taylor 2016).

Similarly, firms with different HQs locations generate different national connections of the JMA in which overseas firms contribute quite significantly, albeit not predominantly, to these connections. One notable feature is that East Asian firms link the JMA with production cities plus Surabaya, while their non-East Asian counterparts are mostly geared towards Surabaya. In a nutshell, regardless of the different categories of firms and the different patterns of urban networks they have created, the integration of the JMA in the global economic system has articulated its respective 'peripheries' into 'the space of global accumulation' (see Friedmann 1995). In other words, the economic growth of the JMA will also (re)shape the economies, albeit to a varying degree, of other Indonesian cities.

On a theoretical level, this study confirms the relevance of a network perspective for studying cities and metropolitan regions, which is in line with the broader paradigmatic shift towards 'relational' thinking in urban geography and urban studies (e.g. Jacobs 2012; Derudder and Taylor 2018). The rise and expansion of the JMA under conditions of contemporary globalization must be understood in relation to its external (i.e. global and national) connections. It is clear that cities 'come in assemblages, ordered as networks' (Taylor, Hoyler, and Verbruggen 2010, 2813). This corroborates Jane Jacobs' core argumentation a couple of decades earlier that 'a city seems always to have implied a group of cities' $(1969,35)$ and that 'cities need one another' $(1984,135)$. Given this, the JMA certainly needs Singapore to tap into wider spaces of flows as well as other cities across the globe to support the metropolis' growth and dynamism which, to a considerable extent, rests on the complex web of spatial divisions of labour. On the other hand, while the JMA is without doubt Indonesia's key gateway to the global 
economy, it also needs other Indonesian cities to perform different roles and functions within an interconnected suite of firms' different activities, ranging from sales and marketing to production.

However, since this study is largely based on a quantitative assessment and secondary sources, we have to treat these conclusions with caution. Qualitative research is needed to more fully understand the complex strategy and organization of (foreign and domestic) firms that affect the location choices of these firms. This research could engage with studies of firm mobility, particularly the line of research that seeks to investigate the internal and external factors driving firm migration as well as the relationship between various organization types of migration and the spatial types of global and local firm migration (e.g. van Dijk and Pellenbarg 2017). Furthermore, future research could also dig deeper into the particular (Indonesian) institutional settings and government interventions at the national and local levels that may have interacted with firms' business strategies, thereby leading to unique patterns of urban networks. One pertinent research question is whether Indonesia's decentralization policy since 2001 has altered the national contours of the manufacturing map as in the case of the European Union’s (EU) ‘Cohesion Policy’ that has successfully attracted various multinationals to invest into EU's peripheral regions (Basile, Castellani, and Zanfei 2008).

\section{References}

Alderson, A.S., and J. Beckfield. 2004. Power and position in the world city system. American Journal of Sociology 109(4): 811-851.

Alderson, A.S., J. Beckfield, and J. Sprague-Jones. 2010. Intercity relations and globalization: The evolution of the global urban hierarchy, 1981-2007. Urban Studies 47(9): 1899-1923.

Amin, A., ed. 1994. Post-fordism: A reader. Oxford: Wiley-Blackwell.

Ando, M., and F. Kimura. 2005. The formation of international production and distribution networks in East Asia. In International trade in East Asia, NBER-East Asia seminar on 
economics, volume 14, eds. T. Ito, and A.K. Rose, 177-216. Chicago \& London: The University of Chicago Press.

Athukorala, P.-C., and N. Yamashita. 2006. Production fragmentation and trade integration: East Asia in a global context. The North American Journal of Economics and Finance 17(3): 233256.

Basile, R., D. Castellani, and A. Zanfei. 2008. Locational choices of multinational firms in Europe: The role of EU cohesion policy. Journal of International Economics 74: 328-340.

Bassens, D., B. Derudder, and F. Witlox. 2010. Searching for the Mecca of finance: Islamic financial services and the world city network. Area 42(1): 35-46.

BPS [Indonesia Statistical Office]. 2011. Population Census 2010. Jakarta: BPS.

BPS [Indonesia Statistical Office]. 2016. Information system and management for basic regional data. http://simreg.bappenas.go.id/view/data/ (accessed 15 February 2017).

Braudel, F. 1984. Civilization and capitalism 15th-18th century. Volume III. The perspective of the world. London: Collins.

Brenner, N. (ed.). 2014a. Implosions / explosions: Towards a study of planetary urbanization. Berlin: Jovis.

Brenner, N. 2014b. Introduction: Urban theory without an outside. In Implosions / explosions: Towards a study of planetary urbanization, ed. N. Brenner, 15-31. Berlin: Jovis.

Castells, M. 1989. The informational city: Information technology, economic restructuring, and the urban-regional process. Oxford: Blackwell.

Castells, M. 2010a. The rise of the network society. 2nd ed. Oxford: Blackwell.

Castells, M. 2010b. Globalisation, networking, urbanisation: Reflections on the spatial dynamics of the information age. Urban Studies 47(13): 2737-2745.

Chow, A.S.Y., and B.P.Y. Loo. 2015. Applying a world-city network approach to globalizing higher education: Conceptualization, data collection and the lists of world cities. Higher Education Policy 28(1): 107-126. 
Coe, N., and H.W.-C. Yeung. 2015. Global production networks: Theorizing economic development in an interconnected world. Oxford: Oxford University Press.

Derudder, B. 2006. On conceptual confusion in empirical analyses of a transnational urban network. Urban Studies 43(11): 2027-2046.

Derudder, B, and P.J. Taylor. 2016. Change in the world city network, 2000-2012. The Professional Geographer 68(4): 624-637.

Derudder, B., and P.J. Taylor. 2018. Central flow theory: comparative connectivities in the worldcity network. Regional Studies 52(8): 1029-1040.

Dick, H.W. 2002. Surabaya, city of work: A socioeconomic history, 1900-2000. Athens, Ohio: Ohio University Press.

Dicken, P. 2005. Tangled webs: Transnational production networks and regional integration. Spatial Aspects Concerning Economic Structures. http://www.spaces-online.unihd.de/include/SPACES\%202005-04\%20Dicken.pdf (accessed 19 July 2018).

Dicken, P. 2015. Global shift: Mapping the changing contours of the world economy. 7th ed. New York: The Guilford Press.

Ducruet, C., D. Ietri, and C. Rozenblat. 2011. Cities in worldwide air and sea flows: A multiple networks analysis. Cybergeo: European Journal of Geography 528. http://cybergeo.revues.org/23603 (accessed 3 September 2018).

Firman, T. 1998. The restructuring of Jakarta Metropolitan Area: A "global city" in Asia. Cities 15(4): 229-243.

Firman, T. 1999a. Indonesian cities under the "Krismon": A great "urban crisis" in Southeast Asia. Cities 16(2): 69-82.

Firman, T. 1999b. From 'global city' to 'city of crisis': Jakarta metropolitan region under economic turmoil. Habitat International 23(4): 447-466.

Fortanier, F. 2007. Foreign direct investment and host country economic growth: Does the investor's country of origin play a role. Transnational Corporations 16(2): 41-76.

Friedmann, J. 1986. The world city hypothesis. Development and Change 17(1): 69-83. 
Friedmann, J. 1995. Where we stand: A decade of world city research. In World cities in a worldsystem, eds. P.L. Knox and P.J. Taylor, 21-41. Cambridge: Cambridge University Press.

Friedmann, J., and G. Wolff. 1982. World city formation: an agenda for research and action. International Journal of Urban and Regional Research 6(3): 309-344.

Frigant, V., and M. Zumpe. 2017. Regionalisation or globalisation of automotive production networks? Lessons from import patterns of four European countries. Growth and Change 48(4): 661-681.

Fujita, M. 2007. The development of regional integration in East Asia: From the viewpoint of spatial economics. Review of Urban and Regional Development Studies 19(1): 2-20.

Gelb, S. (2005). South-South investment: The case of Africa. In Africa in the World economy, eds. J.J. Teunissen and A. Akkerman, 200-205. The Hague: FONDAD.

Goerzen, A., C.G. Asmussen, and B.B. Nielsen. 2013. Global cities and multinational enterprise location strategy. Journal of International Business Studies 44: 427-450.

Graham, S, and S. Marvin. 2001. Splintering urbanism: Networked infrastructures, technological mobilities and the urban condition. London: Routledge.

Hamanaka, S. (2011). FDI in services and regional services and investment agreements: Examination of the Singapore shift in Japan's FDI into ASEAN. ADBI Working Paper 267. Tokyo: Asian Development Bank Institute.

Harrison, J., and M. Hoyler, eds. 2018. Doing global urban research. London: Sage.

Harvey, D. 2005. The condition of postmodernity. Oxford: Blackwell.

Hennart, J.-F., and J. Larimo. 1998. The impact of culture on the strategy of multinational enterprises: Does national origin affect ownership decisions? Journal of International Business Studies 29(3): 515-538.

Hill, H. 1999. The Indonesian economy in crisis: Causes, consequences and lessons. Singapore: Institute of Southeast Asian Studies. 
Holmes, F. 2018. The 6 fastest growing countries in emerging Europe. Forbes, April 5, 2018. https://www.forbes.com/sites/greatspeculations/2018/04/05/the-6-fastest-growingcountries-in-emerging-europe/\#7634de0e57ea (accessed 17 July 2018).

Hoyler, M., T. Freytag, and C. Mager. 2008. Connecting Rhine-Main: The production of multiscalar polycentricities through knowledge-intensive business services. Regional Studies 42(8): 1095-1111.

Hoyler, M., and A. Watson. 2013. Global media cities in transnational media networks. Tijdschrift voor Economische en Sociale Geografie 104(1): 90-108.

Hudalah, D, and A. Aritenang. 2017. Industrial economies on the edge of Southeast Asia metropoles: From gated to resilient economies. In Routledge handbook of Southeast Asian development, eds. A. McGregor, L. Law, and F. Miller, 120-130. Oxon: Routledge.

Hudalah, D., D. Viantari, T. Firman, and J. Woltjer. 2013. Industrial land development and manufacturing deconcentration in Greater Jakarta. Urban Geography 34(7): 950-971. Indraprahasta, G.S., and B. Derudder. 2017. Probing the position of the Jakarta metropolitan area in global inter-urban networks through the lens of manufacturing firms. Asian Geographer 34(2): 147-167.

Indraprahasta, G.S., B. Derudder, and J. Koelemaij. 2018. Global-local dynamics in the transformation of the Jakarta metropolitan area into a global city-region. disP - The Planning Review 54(3): 52-62.

Investor Daily. 2011. Menperin: Pasar domestik jadi tumpuan industri nasional [Minister of Industry: Domestic market as foundation for national industry]. Investor Daily, November 1, 2011. http://www.investor.co.id/tradeandservices/menperin-pasar-domestik-jaditumpuan-industri-nasional/23346 (accessed 20 July 2018).

Jacobs, J. 1969. The economy of cities. New York: Vintage. Jacobs, J. 1984. Cities and the wealth of nations. New York: Vintage. Jacobs, J.M. 2012. Urban geographies I: Still thinking cities relationally. Progress in Human Geography 36(3): 412-422. 
JBIC [Japan Bank for International Cooperation]. 2015. Survey report on overseas business operations by Japanese manufacturing companies. Tokyo: Japan Bank for International Cooperation.

Kimura, F. 2006. International production and distribution networks in East Asia: Eighteen facts, mechanics, and policy implications. Asian Economic Policy Review 1(2): 326-344.

Krätke, S. 2014. How manufacturing industries connect cities across the world: extending research on 'multiple globalizations'. Global Networks 14(2): 121-147.

Leke, A., S. Lund, C. Roxburgh, and A. van Wamelen. 2010. What's driving Africa's growth. McKinsey \& Company, June 2010. https://www.mckinsey.com/featured-insights/middleeast-and-africa/whats-driving-africas-growth (accessed 19 July 2018).

Liu, X., and B. Derudder. 2012. Two-modes networks and the interlocking world city network model: A reply to Neal. Geographical Analysis 44(2): 171-173.

Liu, X., and B. Derudder. 2013. Analyzing urban networks through the lens of corporate networks: A critical review. Cities 31: 430-437.

Lo, F.-C., and Y.-M. Yeung, eds. 1996. Emerging world cities in Pacific Asia. Tokyo: United Nations University Press.

Luo, Y. 1997. Guanxi and performance of foreign-invested enterprises in China: An empirical inquiry. Management International Review 37(1): 51-70.

Lüthi, S., A. Thierstein, and M. Bentlage. 2013. The relational geography of the knowledge economy in Germany. On functional urban hierarchies and localised value chain systems. Urban Studies 50(2): 276-293.

Lüthi, S., A. Thierstein, and V. Goebel. 2010. Intra-firm and extra-firm linkages in the knowledge economy: The case of the emerging mega-city region of Munich. Global Networks 10(1), 114137.

Lüthi, S., A. Thierstein, and M. Hoyler. 2018. The world city network: Evaluating top-down versus bottom-up approaches. Cities 72(B): 287-294.

Mans, U. 2014. Revisiting city connectivity. Journal of Economic Geography 14: 155-177. 
Martinus, K., and M. Tonts. 2015. Powering the world city system: Energy industry networks and interurban connectivity. Environment and Planning A 47(7): 1502-1520.

OECD. 2008. Staying competitive in the global economy. Paris: OECD.

Oh, C.H., and A.M. Rugman. 2012. Regional integration and the international strategies of large European firms. International Business Review 21(3): 493-507.

Olds, K., and H.W.-C Yeung. 2004. Pathways to global city formation: A view from the developmental city-state of Singapore. Review of International Political Economy 11(3): 489521.

Pauly, L.W., and S. Reich. 1997. National structures and multinational corporate behavior: Enduring differences in the age of globalization. International Organization 51(1): 1-30.

Pflieger, G., and C. Rozenblat. 2010. Introduction. Urban networks and network theory: The city as the connector of multiple networks. Urban Studies 47(13): 2723-2735.

Rakhmat, M.Z. 2016. Indonesia: A potential partner for Gulf States. The Diplomat, May 19, 2016. https://thediplomat.com/2016/05/indonesia-a-potential-partner-for-gulf-states/ (accessed 20 July 2018).

Reid, A. 1980. The structure of cities in Southeast Asia, fifteenth to seventeenth centuries. Journal of Southeast Asian Studies 11: 235-250.

Robinson, J. 2002. Global and world cities: A view from off the map. International Journal of Urban and Regional Research 26(3): 531-554.

Rugman, A. M., and A. Verbeke. 2004. A perspective on regional and global strategies of multinational enterprises. Journal of International Business Studies 35(1): 3-18.

Rugman, A. M., and A. Verbeke. 2005. Toward a theory of regional multinationals: A transaction cost economics approach. Management International Review 45(S1): 5-17.

Rutherford, J. 2005. Networks in cities, cities in networks: Territory and globalisation intertwined in telecommunications infrastructure development in Europe. Urban Studies 42(13): 2389-2406. 
Salna, K., and H. Amin. 2018. Indonesia says its huge domestic market will protect it from trade war. Bloomberg, April 5, 2018. https://www.bloomberg.com/news/articles/2018-0405/indonesia-says-domestic-market-to-shelter-economy-from-trade-war (accessed 20 July 2018).

Sassen, S. 1991. The global city: New York, London, Tokyo. 1st ed. Princeton, NJ: Princeton University Press.

Schmitt, P., and L. Smas. 2012. Nordic 'intercity connectivities' in a multi-scalar perspective. Nordregio Working Paper 2012:7.

Sheany, S. 2018. Indonesia forges stronger path to boost relations with Africa. Jakarta Globe, April 16, 2018. http://jakartaglobe.id/news/indonesia-forges-stronger-path-boostrelations-africa/ (accessed 20 July 2018).

Sheppard, E. 2002. The spaces and times of globalization: Place, scale, networks, and positionality. Economic Geography 78(3): 307-330.

Sigler, T.J., and K. Martinus. 2017. Extending beyond 'world cities' in world city network (WCN) research: Urban positionality and economic linkages through the Australia-based corporate network. Environment and Planning A 49(12): 2916-2937.

Smith, D. A., and M. Timberlake. 2002. Hierarchies of dominance among world cities: a network approach. In Global Networks, Linked Cities, ed. S. Sassen, 117-141. London: Routledge.

Soegijoko, B.T. 1996. Jabotabek and globalization. In Emerging world cities in Pacific Asia, eds. F.C Lo, and Y.-M. Yeung, 377-414. Tokyo: United Nations University Press.

Taylor, P.J. 2001. Specification of the world city network. Geographical Analysis 33(2): 181-194. Taylor, P.J. 2004. World city network: A global urban analysis. London \& New York: Routledge. Taylor, P.J. 2012. Extraordinary cities: Early 'city-ness' and the origins of agriculture and states. International Journal of Urban and Regional Research 36(3): 415-447.

Taylor, P.J. 2014. A research odyssey: From interlocking network model to extraordinary cities. Tijdschrift voor Economische en Sociale Geografie 105(4): 387-397. 
Taylor, P. J., and B. Derudder. 2016. World city network: A global urban analysis. 2nd ed. New York: Routledge.

Taylor, P.J., and B. Derudder. 2018. Exploring the world city network. In Doing Global Urban Research, eds. J. Harrison, and M. Hoyler, 34-51. London: Sage.

Taylor, P.J., B. Derudder, J. Faulconbridge, M. Hoyler, and P. Ni. 2014. Advanced producer service firms as strategic networks, global cities as strategic places. Economic Geography 90(3): 267-291.

Taylor, P.J., M. Hoyler, and R. Verbruggen. 2010. External urban relational process: Introducing central flow theory to complement central place theory. Urban Studies 47: 2803-2818.

Townsend, A.M. 2001. Network cities and the global structure of the internet. American Behavioral Scientist 44: 1697-1716.

van Dijk, J., and P. H. Pellenbarg. 2017. Firm migration. In The international encyclopedia of geography, eds. D. Richardson, N. Castree, M. F. Goodchild, A. Kobayashi, W. Liu, and R. A. Marston, 1-12. Malden, MA and Oxford, UK: John Wiley \& Sons.

Verbruggen, R. 2011. World cities before globalisation: The European city network, A.D. 13001600. PhD Dissertation. Loughborough University.

Wall, R. S., and G.A. van der Knaap. 2011. Sectoral differentiation and network structure within contemporary worldwide corporate networks. Economic Geography 87(3): 267-308.

World Bank. 1993. The East Asian miracle: Economic growth and public policy. New York: Oxford University Press.

Yeung, H.W.-C., and K. Olds. 1998. Singapore's global reach: Situating the city-state in the global economy. International Journal of Urban Sciences 2(1): 24-47.

Yuswohady, Y. 2014. Global chaser: Merek Indonesia perkasa di pentas dunia [Global chaser: Powerful Indonesian brands on the world stage]. Jakarta: Gramedia Pustaka Utama. Zhang, X., and R. Kloosterman. 2016. Connecting the 'workshop of the world': Intra- and extraservice networks of the Pearl River Delta city-region. Regional Studies 50(6): 1069-1081. 
Table 1. Distribution of firms' HQs

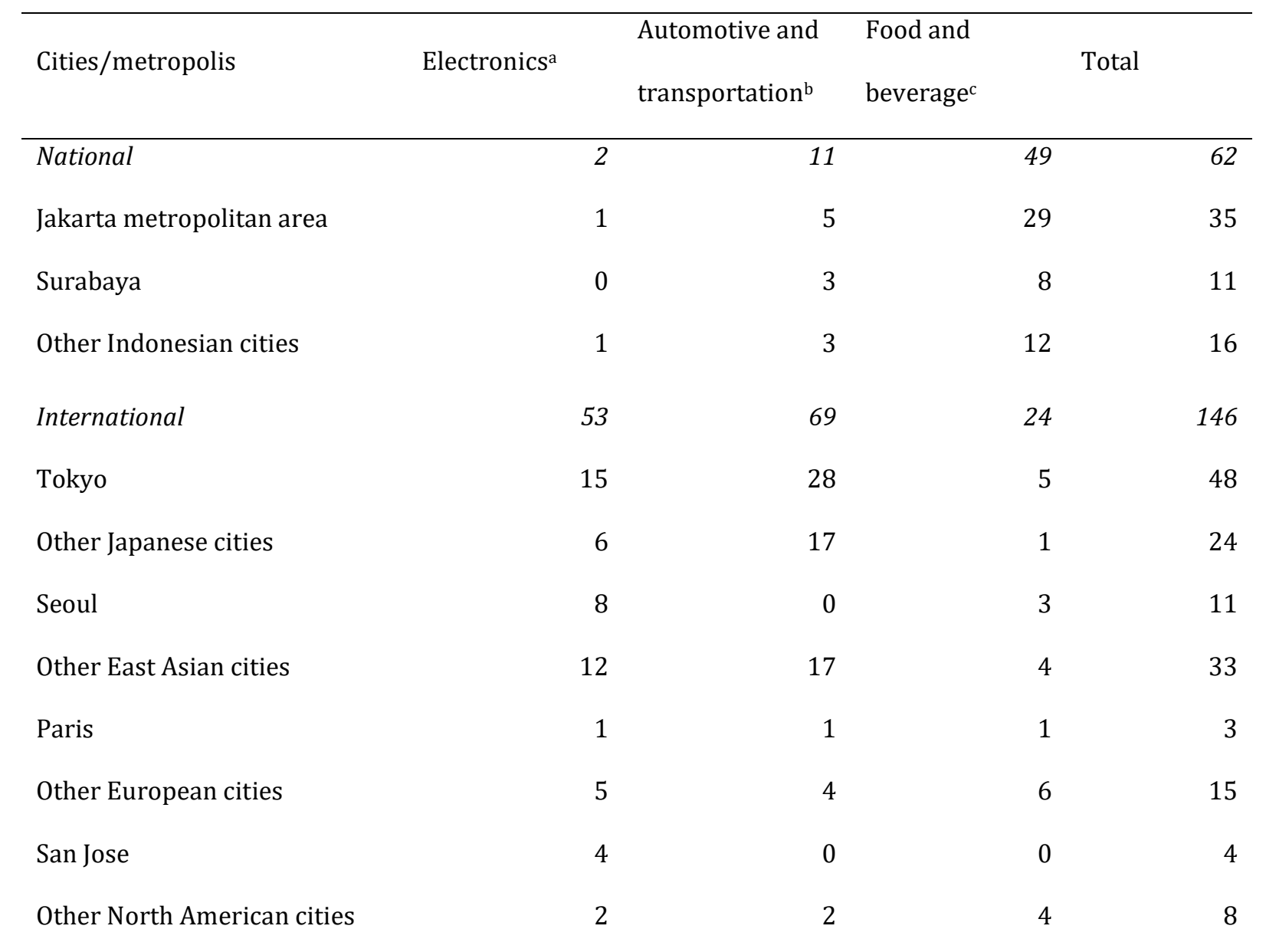

Note: There are a2 electronics, b7 automotive and transportation, and c3 food and beverage TNCs with global HQs located in 2 different cities/metropolises 
Table 2. Top twenty-five global connections of the JMA for firms with different HQs locations

\begin{tabular}{|c|c|c|c|c|c|c|}
\hline Rank & East Asian firms & CDC & Non-East Asian firms & CDC & JMA firms & CDC \\
\hline 1 & Tokyo & 1.000 & Singapore & 1.000 & Kuala Lumpur & 1.000 \\
\hline 2 & Singapore & 0.677 & Paris & 0.891 & Singapore & 1.000 \\
\hline 3 & Bangkok & 0.634 & Tokyo & 0.816 & Lagos & 1.000 \\
\hline 4 & Shanghai & 0.519 & Kuala Lumpur & 0.680 & Ipoh & 0.667 \\
\hline 5 & Seoul & 0.498 & Dubai & 0.672 & Metro Manila & 0.667 \\
\hline 6 & Hong Kong & 0.391 & London & 0.672 & Ho Chi Minh City & 0.667 \\
\hline 7 & Kuala Lumpur & 0.374 & Moscow & 0.648 & Jeddah & 0.667 \\
\hline 8 & Beijing & 0.361 & Shanghai & 0.645 & Nairobi & 0.667 \\
\hline 9 & Osaka & 0.347 & Bangkok & 0.629 & Shanghai & 0.333 \\
\hline 10 & Metro Manila & 0.334 & Sao Paulo & 0.629 & Shenzhen & 0.333 \\
\hline 11 & London & 0.334 & Sydney & 0.617 & Xiamen & 0.333 \\
\hline 12 & Sao Paulo & 0.331 & Seoul & 0.613 & Ayutthaya & 0.333 \\
\hline 13 & Taipei & 0.324 & Milan & 0.609 & Bangalore & 0.333 \\
\hline 14 & Ho Chi Minh City & 0.308 & Warsaw & 0.598 & Chennai & 0.333 \\
\hline 15 & Nagoya & 0.290 & Toronto & 0.570 & Dammam & 0.333 \\
\hline 16 & Hanoi & 0.276 & Hong Kong & 0.566 & Adra & 0.333 \\
\hline 17 & Paris & 0.272 & Zurich & 0.555 & Aden & 0.333 \\
\hline 18 & Gurgaon & 0.264 & Metro Manila & 0.551 & Cairo & 0.333 \\
\hline 19 & Moscow & 0.250 & Mexico City & 0.543 & Bishoftu & 0.333 \\
\hline 20 & Los Angeles & 0.243 & Beijing & 0.539 & Mombasa & 0.333 \\
\hline 21 & Dubai & 0.238 & Athens & 0.539 & Tiflet & 0.333 \\
\hline 22 & Mexico City & 0.225 & Istanbul & 0.527 & Port Harcourt & 0.333 \\
\hline 23 & Toronto & 0.219 & Prague & 0.523 & Kaduna & 0.333 \\
\hline 24 & Sydney & 0.211 & Buenos Aires & 0.520 & Khartoum & 0.333 \\
\hline 25 & Frankfurt & 0.198 & Taipei & 0.512 & Indjija & 0.333 \\
\hline
\end{tabular}

Note: The CDC is shown as a proportion of the most connected city-dyad with the JMA (i.e. Tokyo for East Asian firms, Singapore for non-East Asian firms, and Kuala Lumpur for JMA firms) 
Table 3. Top ten national connections of the JMA for firms with different HQs locations

\begin{tabular}{|c|c|c|c|c|c|c|c|c|}
\hline \multirow[b]{2}{*}{ Rank } & \multirow{2}{*}{$\begin{array}{l}\text { East Asian } \\
\text { firms }\end{array}$} & \multirow[b]{2}{*}{$\mathrm{CDC}$} & \multicolumn{2}{|l|}{ Non-East Asian } & \multirow[b]{2}{*}{ JMA firms } & \multicolumn{3}{|c|}{ Non-JMA } \\
\hline & & & firms & $\mathrm{CDC}$ & & $\mathrm{CDC}$ & firms & $\mathrm{CDC}$ \\
\hline 1 & Karawang & 1.00 & Surabaya & 1.00 & Surabaya & 1.00 & Surabaya & 1.00 \\
\hline 2 & Surabaya & 0.47 & Karawang & 0.29 & Semarang & 0.95 & Medan & 0.45 \\
\hline 3 & Batam & 0.45 & Semarang & 0.29 & Karawang & 0.62 & Bandung & 0.41 \\
\hline 4 & Pasuruan & 0.25 & Makassar & 0.21 & Bandung & 0.62 & Semarang & 0.27 \\
\hline 5 & Purwakarta & 0.22 & Bandung & 0.14 & Medan & 0.60 & Denpasar & 0.15 \\
\hline 6 & Makassar & 0.18 & Pasuruan & 0.14 & Makassar & 0.60 & Surakarta & 0.10 \\
\hline 7 & Sukabumi & 0.14 & Medan & 0.14 & Palembang & 0.43 & Pati & 0.08 \\
\hline 8 & Cilacap & 0.14 & Palembang & 0.14 & Serang & 0.35 & Tegal & 0.08 \\
\hline 9 & Serang & 0.12 & Luwu Timur & 0.14 & Banjarmasin & 0.35 & Batang & 0.08 \\
\hline 10 & Jombang & 0.12 & Balikpapan & 0.14 & Sukabumi & 0.32 & Pasuruan & 0.08 \\
\hline
\end{tabular}

Note: The CDC connectivity is shown as a proportion of the most connected city-dyad with the JMA (i.e. Karawang for East Asian firms, Surabaya for non-East Asian, JMA, and non-JMA firms) 
Figure 1

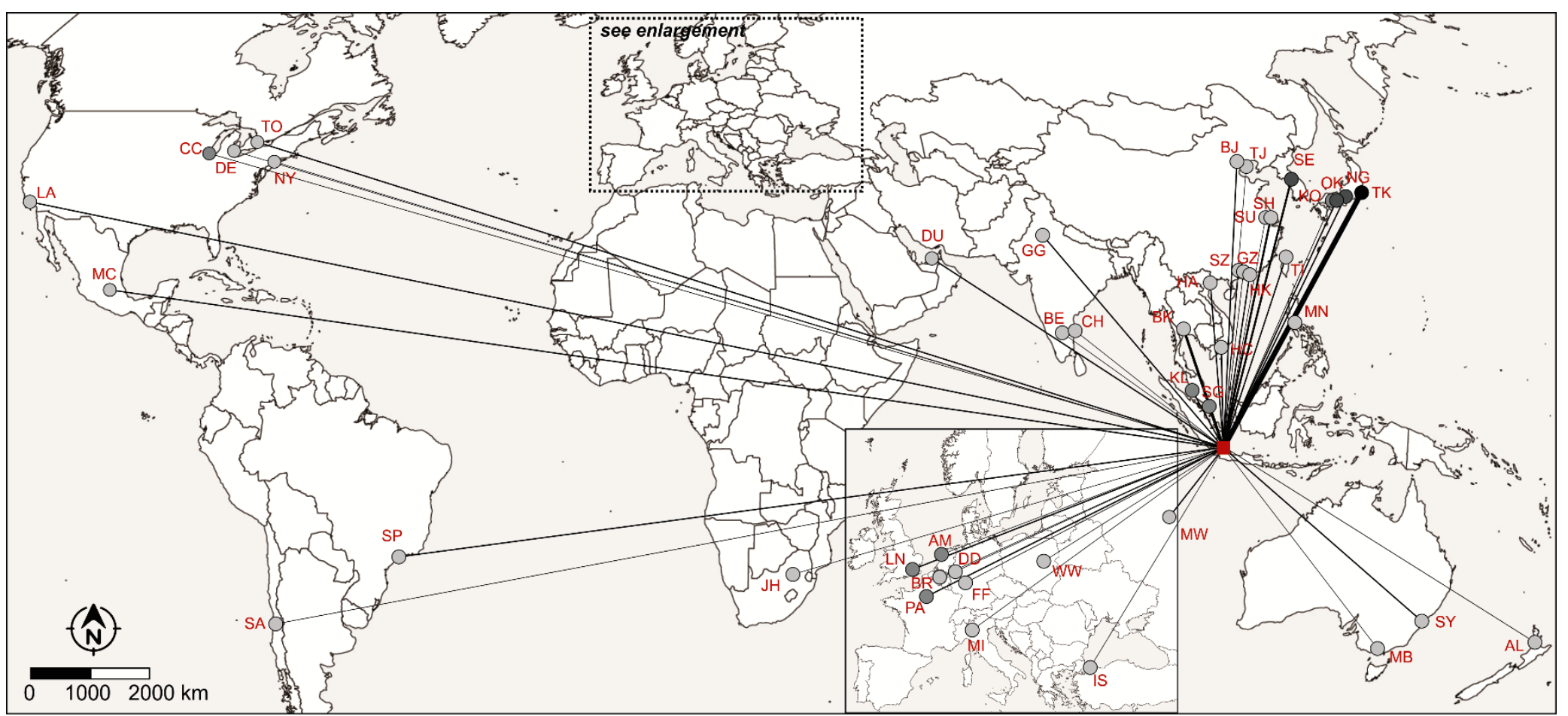

City-Dyad Connectivity (CDC) Number of Global HQs

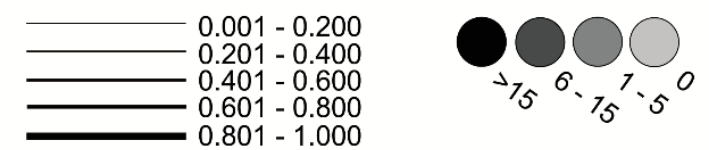

Jakarta metropolitan area
$\mathrm{AL}=$ Auckland $\mathrm{AM}=\mathrm{Amsterdam}, \mathrm{BE}=\mathrm{Bangalore}, \mathrm{BJ}=\mathrm{Beiing}, \mathrm{BK}=$ Bangkok, $\mathrm{BR}=$ Brussels, $\mathrm{CC}=$ Chicago, $\mathrm{CH}=$ Chennai, $\mathrm{DD}=$ Dusseldorf (Rhine North), $\mathrm{DE}=$ Detroit, $\mathrm{DU}=$ Dubai, $\mathrm{FF}=$ Frankfurt $G G=$ Gurgaon, $G Z=$ Guangzhou, $H A=$ Hanoi, $H C=H o$ Chi Minh City, $H K=$ Hong Kong, IS =

Istanbul, $\mathrm{JH}=$ Johannesburg, $\mathrm{KL}=$ Kuala Lumpur, $\mathrm{KO}=$ Kobe, $\mathrm{LA}=$ Los Angeles, $\mathrm{LN}=$ = London, $\mathrm{MB}$ = Melbourne, $\mathrm{MC}=$ Mexico City, $\mathrm{Ml}=$ Milan, $\mathrm{MN}=$ Metro Manila, MW = Moscow, NG = Nagoya, NY New York, OK = Osaka, PA = Paris, $\mathrm{SA}=$ Santiago, $\mathrm{SE}=$ Seoul, $\mathrm{SG}=$ Singapore, $\mathrm{SH}=$ Shanghai, $\mathrm{SP}=$ Sao Paulo, $\mathrm{SU}=$ Suzhou, $\mathrm{SY}=$ Sydney, SZ = Shenzhen, $\mathrm{TI}=$ Taipei, $\mathrm{TJ}$ = Tianjin, $\mathrm{TK}=$ Tokyo, $\mathrm{TO}=$ Toronto, $\mathrm{WW}=$ WarsaW 
Figure 2

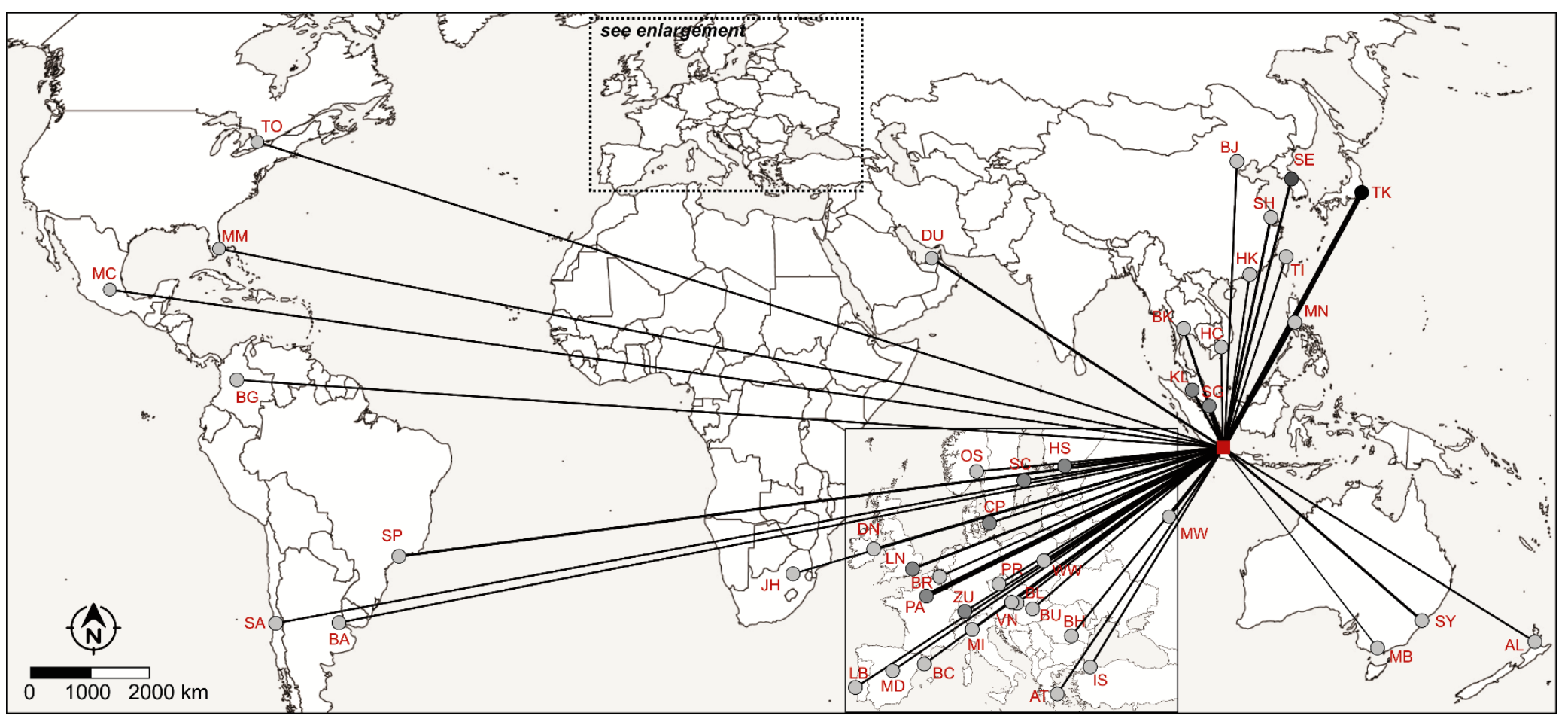

City-Dyad Connectivity (CDC) Number of Global HQs

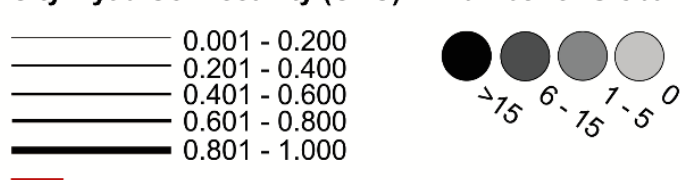

$\mathrm{AL}=$ Auckland $\mathrm{AT}=\mathrm{Athens}, \mathrm{BA}=$ Buenos Aires, $\mathrm{BC}=$ Barcelona, $\mathrm{BG}=$ Bogota, $\mathrm{BH}=$ Bucharest $\mathrm{BJ}$ $=$ Beijing, $\mathrm{BK}=$ Bangkok, $\mathrm{BL}=$ Bratislava, $\mathrm{BP}=$ Budapest, $\mathrm{BR}=$ Brussels, $\mathrm{CP}=$ Copenhagen, $\mathrm{DN}=$ Dublin, DU = Dubai, $\mathrm{HC}=\mathrm{Ho}$ Chi Minh City, $\mathrm{HK}=$ Hong Kong, $\mathrm{HS}=$ Helsinki, IS = Istanbul, JH =

Johannesburg, $\mathrm{KL}=$ Kuala Lumpur, $\mathrm{LB}=$ Lisbon, $\mathrm{LN}=$ London, $\mathrm{MB}=$ Melbourne, $M C=$ Mexico City, $\mathrm{MD}=$ Madrid, $\mathrm{MI}=$ Milan, $\mathrm{MM}=$ Miami, $\mathrm{MN}=$ Metro Manila, $\mathrm{MW}=$ Moscow $, \mathrm{OS}=\mathrm{Oslo}, \mathrm{PA}=$ Paris, $\mathrm{PR}=$ Prague, $\mathrm{SA}=$ Santiago, $\mathrm{SC}=$ Stockholm, $\mathrm{SE}=$ Seoul, $\mathrm{SG}=$ Singapore, $\mathrm{SH}=$ Shanghai, $\mathrm{SP}=$ Sao Paulo, SY = Sydney, $\mathrm{TI}=$ Taipei, $\mathrm{TK}=$ Tokyo, $\mathrm{TO}=$ Toronto, $\mathrm{VN}=$ Vienna, WW = Warsaw, ZU =

Jakarta metropolitan area Zurich 
Figure 3

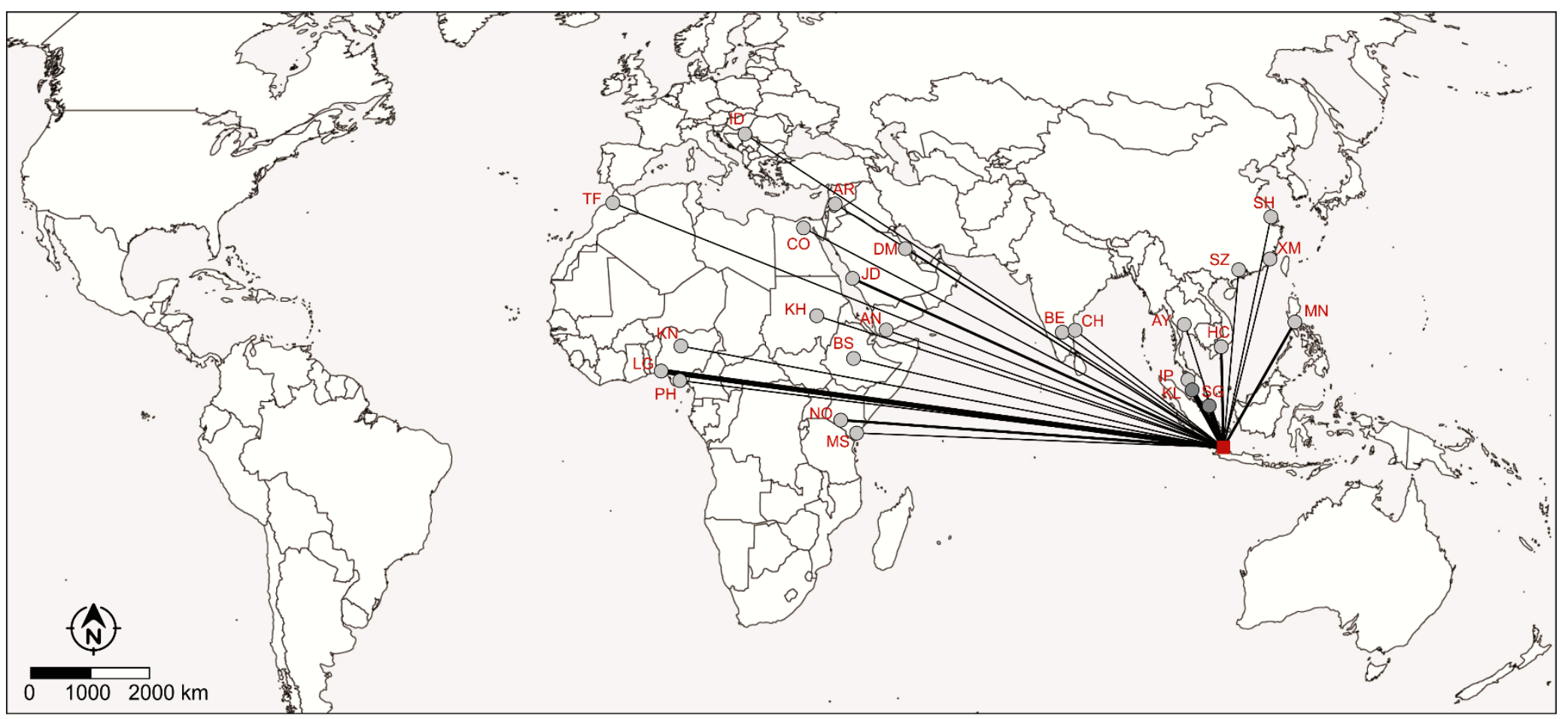

City-Dyad Connectivity (CDC) Number of Global HQs

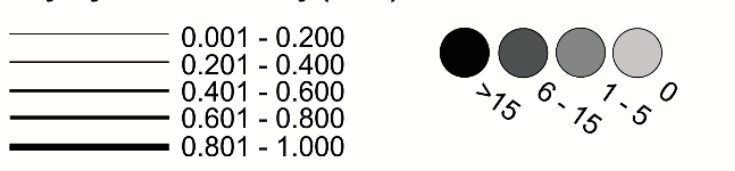

$\mathrm{AN}=$ Aden $, \mathrm{AR}=\mathrm{Adra}, \mathrm{AY}=$ Ayutthaya, $\mathrm{BE}=$ Bangalore, $\mathrm{BS}=$ Bishoftu, $\mathrm{CH}=$ Chennai, $\mathrm{CO}=$ Cairo, $\mathrm{DM}=$ Dammam, $\mathrm{HC}=\mathrm{Ho}$ Chi Minh City, ID = Indjija, IP = Ipoh, JD = Jeddah, $\mathrm{KH}=$ Khartoum, $\mathrm{KL}=$ Kuala Lumpur, KN = Kadouna, $L G=$ Lagos, MN = Metro Manila, MS = Mombassa, NO = Nairobi, $\mathrm{PH}$ $=$ Port Harcourt, $S G=$ Singapore, $S H=$ Shanghai, $S Z=$ Shenzhen, $T F=$ Tiflet, $X M=$ Xiamen

Jakarta metropolitan area 
